\title{
I'm fine: Gender and modest displays of mental distress
}

\author{
Hans T. Sternudd
}

In this article I will provide examples of intermedial representations of emotions and feelings that consists of images and texts appearing in the same visual field in a meme, that has here has been called the I'm-fine meme. I will argue that this meme can be understood as a sign in a discourse that articulates mental distress in a way that limits the possible ways in which girls and young women can express their experiences of bad feelings.

The purpose of this study is to examine examples of gendered articulations of mental distress in a special meme, that I name the 'I'm-fine meme'. It is a meme spread through different internet platforms that combines the text 'I'm fine' with an image or images and sometimes also additional texts. It is usually published in an image format (in this case often as jpg/jpeg or png). The I'm-fine meme is characterised by juxtaposing the positive message with contradictive representations of mental distress in textual or image forms. As all internet memes it is characterised by evolving and transforming through mutations or remixes during as it spreads over the internet (Knobel \& Lankshear 2005:13-14). ${ }^{1}$ In focus are intermedial memes that combine text content with image content. The questions I am asking are as follows: What kinds of articulations of mental distress are found in the I'm-fine meme? Do these articulations follow a gendered binarism? If so, which attributes of mental distress are connected to gendered coded bodies?

\section{The point of departure}

In the following, "mental distress" and "bad feelings" are terms that are used to cover a wide range of unpleasant and disturbing inner experiences. They allude to a situated experience, emanating from a user-oriented perspective, but should not to be seen as theoretical concepts used in the analysis. Mental distress is understood here as something made intelligible, enacted and represented in different ways depending on the sociocultural situation. The characteristics of mental distress have been subjects for studies that have shown how mental distress is connected to femininity and women's physical constitution (see e.g. Showalter 1987; Tatman 2012; Ussher 2011). The point of departure for the study is that it is important to study representations of mental distress because in these specific expressions: sayings, acts, body postures etc. are made possible while others become impossible. This repertoire of possible expressions varies between groups, which are often established by the gendering of bodies. Discussing the causal connection between being exposed to certain visual/verbal

\footnotetext{
${ }^{1}$ This definition of a meme contradicts Dawkins' original meaning which denotes "all non-genetic behaviour and cultural ideas" (Börzsei 2013:3), quite stable concepts that are interpersonally spread (Dawkins, 2006:189-201). On memes see also Davidson 2012. Often a distinction is made between something going "viral" and a meme. "A meme has the ability to evolve; something that has gone viral may not have that ability" (Myhre 2012; see also Börzsei 2013:4; Shifman 2011:188).
} 
representations and individuals' activities is outside the scope of this study. Even so, potential interpellating effects on viewers who identify themselves with the characters and concepts in the memes in question should not be neglected. ${ }^{2}$

My previous interest in situated meaning making and knowledge has in part guided the collection of material that is used in this article. ${ }^{3}$ The use of common search engines such as Google Images and user-generated material from the community DeviantArt are guided by this interest. DeviantArt is an interactive site where members can "like" and comment on the uploaded material, ${ }^{4}$ their own as well as others' (Wikipedia 2015). An interest in young individuals' representations of bad feelings is also reflected in choosing the material from this source, as DeviantArt, judging from its stylistic features as well as its members' skills and choice of subjects, seems to be dominated by teenagers and young adults. The published material can therefore reflect articulations on important and engaging subjects among this group.

\section{Previous research and theoretical approach}

Research on visual and verbal representations of mental distress is a wide and heterogeneous field. The studies mentioned in this section are examples of some different approaches to the subject. Artists who have suffered from mental illness have attracted great interest, see for instance Cullberg's (1999) and Nilsson's (1977) writing on the Swedish artist Carl Fredrik Hill. For an overview of art by those who has labelled in the past as "insane", see MacGregor (1989) and the case study on Ester Henning in Bergström (2001). Frida Kahlo's paintings, which often addressed her personal suffering, have generated a vast amount of studies (for an overview see Zetterman 2003:15-22). Art is also used as a therapeutic device (see e.g. Milia 2000), and the work of artists has been analysed using psychoanalytic methods (e.g. Nagera 1967). Texts about eating disorders that have been published on the internet have been examined in relation to identity (Giles 2006), narration (Dias 2003) and constructed bodies (Ward 2007).

The construction of the mentally distressed subject has been scrutinised from gender perspectives. Showalter argues in her study on the conception of woman and madness in England in the 20th and 21st century that madness was seen "as the essential feminine nature" (1987:3). This notion was reproduced in both texts and images, for instance in visual depictions of the drowned Ophelia (Showalter 1987:11). Images of woman's ill health, both in a figurative sense in verbal accounts and in images, in the fin-de-siècle have been studied by Johannisson (1994). In a study of later empirical data, images of depressed in drug advertising, the writers conclude that the symptom-bearer in all the cases was a woman (Sandström \& Johansson 2004). Critical feminist perspectives on the tendency to interpret the work of female artists as autobiographical representations of their physical and/or mental sufferings, has been put forward by Pollock (2007; 2012).

\footnotetext{
${ }^{2}$ On interpellation see Winther Jørgensen \& Philips 2002:41.

${ }^{3}$ See e.g. Sternudd 2012; 2014.

4 The site was launched in 2000; it has over 35 million registered members and over 160,000 works are uploaded every day, according to the owners of the site (DeviantArt 2016).
} 
Critical internet studies focusing on gender, race, and postcolonial perspectives has among others been done by White (2006). Another example is Nakamura's (2008) studies on racial and gendered representations on internet (for instance in avatars and animated GIF-files). Mentioned should also Edmondson (2013) who in her dissertation explored images posted on blogs the dealt with questions related to self-harm with a similar method as in the study here. Together with ethnologist Anna Johansson, I have in previous studies examined representations of suffering in different places on the internet from discursive and gender perspective. These studies have focussed on iconographic signs for suffering, like the sitting girl (Sternudd \& Johansson 2015; Johansson \& Sternudd 2015), and for the masculine anomaly of the emo boy (Johansson \& Sternudd 2016).

In this article expressions of mental distress are understood as culturally coded, which is in line with the theory of cultural diseases (Hacking 1999; Johannisson 1994; Showalter 1987), a theory that claims that the configuration and staging of mental distress follows discursive prescriptions and values. This in no way relativizes the individual sufferings that are connected to mental distress. It only suggests that the articulations of mental distress are contingent; they are specific for each historical, social and cultural epoch. This means that in order to be recognised as somebody suffering from mental distress it is necessary to perform it in a correct and recognisable way. ${ }^{5}$

The analysis of the I'm-fine meme is grounded on discourse theory (DT) as formulated by Laclau and Mouffe (2001). DT postulates that meaning is produced through relations between signs in networks, so-called chains of equivalences (Laclau \& Mouffe 2001:110). Elements are signs with uncertain relations to other signs. When an element has achieved a temporarily fixed relation through articulation, it becomes a moment (Laclau \& Mouffe 2001:105-114; Winther Jørgensen \& Philips 2002:28). A discourse is a fixation of meaning in a certain domain. I suggest that the I'm-fine meme appears in an order of discourse, a terrain constituted by different discourses that articulate mental distress. An order of discourse is understood as a fictive field in which discourses with the goal of articulating a phenomenon appear (Winther Jørgensen \& Philips 2002:27). Mental distress is in this order a floating signifier, an element of exceptional significance that is particularly open for inscriptions and that different discourses are trying to give meaning to (Winther Jørgensen \& Philips 2002:28). With its emphasis on the constructiveness of meaning DT fits well with a poststructuralist understanding of gendered bodies who are constituted through a series of performative and imitative acts, "structured along matrices of gender hierarchy and compulsory heterosexuality" (Butler 2006 [1990/1999]: 198). This "heterosexual matrix" (Butler 2006 [1990/1999]: xxx) is founded on binary concept of gender, a concept that only permits two configurations: men and women.

Sign is here used in the semiotic meaning as one thing that stands for another thing, in this study the things are visual representations of text and images. The meaning of signs varies according to the context, i.e. the discourse the perceiver appear in. Signs can be perceived as grounded on conventions (symbolic), resemblance (iconic) or contiguity (indexical) (see

\footnotetext{
5 On performing mental illness in a correct way in internet communities for self-injurers see Johansson 2010a:196-195.
} 
Marner 1999 and Elleström 2010 for overviews and discussions). In this study are signs understood as processual, relational and unstable "things".

\section{Method}

The material for this study was generated first by using Google Images and later a search engine on DeviantArt. Google Images was selected because of its dominating position as the search engine used by the majority of internet users and because search results are presented according to the result that attracted the most users (Internet Live Stats 2016). If a page is chosen more often in Google searches it gets a higher ranking and position in the search result (Sobek 2003a). Google is a highly influential actor on the internet: Page and Brin's famous PageRank algorithm rules millions of users' choice of information every day (Sobek 2003b). Researchers in the field of discourses established on the internet can therefore take advantage of Google search's dominant position in the explorations for highly popular and widely spread material.

A search for the phrase "I'm fine" on Google Images generated nearly 800 image files. In the search, the function "Hide private results" was used to avoid search results based on my own search history. As many of the files generated through Google came from DeviantArt, in the form of images (as painting, drawings and photographs), texts (mostly poetry) and combinations of image and text, a search was made on this site as well. This search used \#imfine, which generated over 400 image files. This means that material from the community DeviantArt has more influence over the result than Google Images, which covers material on the whole web. This means that the result presented here cannot be seen as representative for the web in general. The collecting of material was halted when some categories was repeated with variations of the same type of representation. In the next phase the material was sorted: doubles' and images without the phrase "I'm fine" were excluded, as well image files containing only text. Commercial material was also left out, as otherwise it would have dominated the sample too much. After this procedure was complete, nearly 500 images remained.

This sample was analysed with the help of content analysis inspired by among others Lutz and Collins (1993). ${ }^{6}$ Content analysis has over the years been a tool used to draw attention to gender inequalities, for instance gender bias in media (cf. The Global Media Monitoring Project 2015). The advantage with this method is that it works against the analysts preconceptions, it protects from findings that only confirm one's initial sense of what the photos say or do (Lutz and Collins 1993:89). An inductive approach was guiding the coding of the material which means that "the categories and names for categories flow from the data" (Hsieh \& Shannon 2005:1279). To be able to answer the question about occurrence of gender binarism in the material this rule against preconceived categories was in this case discarded.

\footnotetext{
${ }^{6}$ For an overview see Rose 2012:81-104.
} 
As Lutz and Collins points out in the process of reducing an image with its complexity to a couple of words ignores many of its features (1993:89). But to create an overview, an overall pattern (in a visual discourse), images needs to be reduced to a couple of components "that can be labelled in a way that has some analytical significance" (Rose 2012:91). The analyst should throughout this process strive to achieve categories that are as exclusive and enlightening as possible. Which means to divide the material into mutually exclusive categories, that are analytically relevant and consistent (Rose 2012:91, see also Lutz \& Collins 1993:88-89). In the coding process NVivo, software for qualitative data analysis, was used. With this program the images was marked with one or several tags that was organised into different clusters. Two types of categories were noted: 1) a intermedial content relations, meaning relations between the content of the image and the text, ${ }^{7}$ were affirmations or contradiction between different media in the memes; 2) the iconic image content, a category included certain variants that appear in several variations. ${ }^{8}$

Before I continue some notes on analytic problems and the process of coding. As one of the aims of this study is to examine gendered articulations in the material, a rough categorisation was made according to a binary division - female and male. This categorisation was in part due to the frequent use of the pronoun "she" in reference to the depicted persons. There is always a risk of affirming stereotypical gendered notions when a division like this is made, and therefore the categorisation should be understood as a tentative, but necessary, one for an analysis of gendered representations. Gendered representations of bodies were identified by significant bodily features, such as hairstyles or make-up, etcetera, features that in the West are usually seen as gender specific. To reduce biases in the analysis of gender the context of publication was consulted. If, for instance, the person represented in the image was commented by the publisher like this: "check her out shes awesome" (Sweetwii044 2012), ${ }^{9}$ the category female was affirmed. The signifiers of mental distress, described below, were validated in the same way. For instance depiction of tears in an image, that possible could be tears representing a joyful cry, was checked with the same method. If a drawing of crying person with the additional text "I'm fine" is published together with the comment "But in the inside you're really not" (Starwa 2011), it indicates some kind of mental distress. In this way the categories of every tenth of the coded memes were checked for bias.

\footnotetext{
${ }^{7}$ In the analysis the iconic content (which is part of the visual mode that resembles something else) of the images was noted.

${ }^{8} \mathrm{~A}$ variant is here defined as a composition/configuration with a certain structure, while a variation is one concrete example of the variant.

${ }^{9}$ Language irregularities in the quotes from the comment section are not commented upon (with sic) or corrected, as this could be apprehended as a pejorative action and removing the special character of internet lingua.
} 


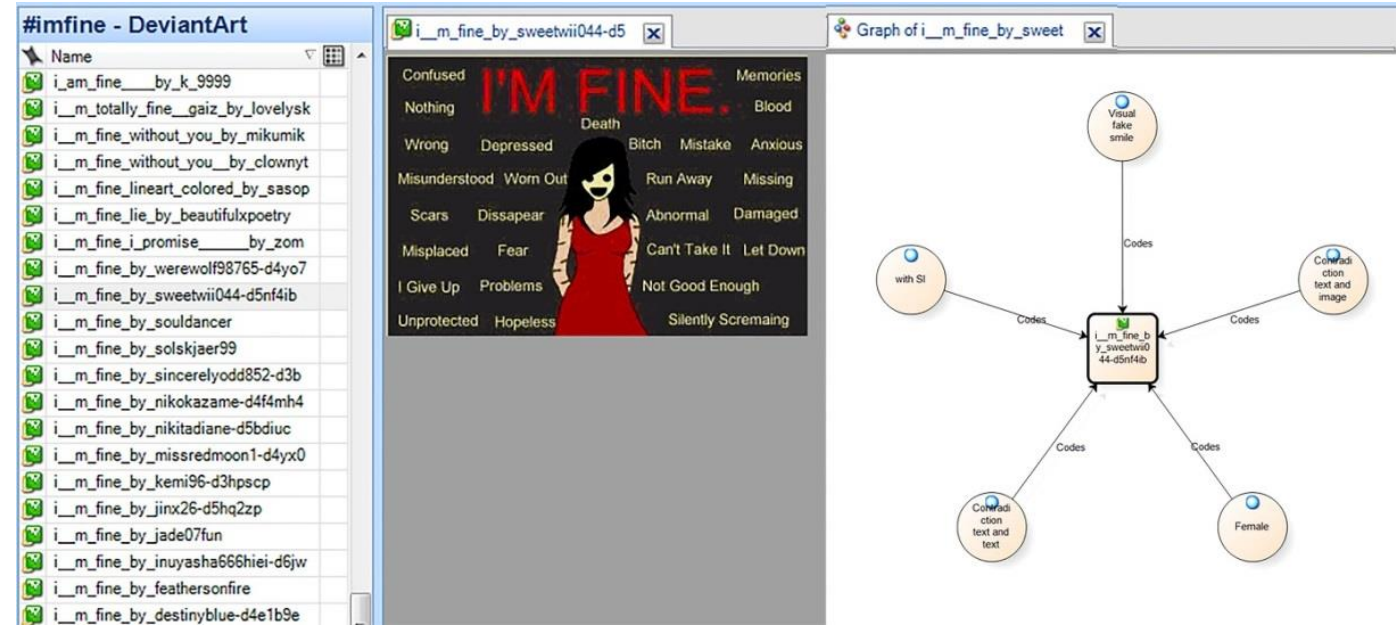

Figure 1. Screenshot from NVivo analysis. Image: I'm Fine by Charley AKA Sweetwii044: () Charley 2012. Published with permission from the copyright holder

How the method worked can be exemplified with the coding of Sweetwii044's meme that was published on DeviantArt 2012. A screen shot with a detail from NVivo (see figure 1) shows a part of the list of memes to the left, the meme in the middle and a visualisation of the codes that has been attached to the meme in the analyse. In this example Sweetwii044's meme has been attached with the code female based on bodily features of the represented person, the hairstyle and shape of breasts that all are equivalent to a female body in a hegemonic Western discourse. The sleeveless dress the person wears in the image is a garment connected to females. Positioning the meme in this discourse is based on several factors: the publicist's origin in UK, according to her record on DeviantArt and English being the dominating language on the site and an overall impression of the site. Sweetwii044's meme is also coded a "with SI" which means that is has representations that relates to self-injury. In this meme represented as twelve black lines on the arms of the girl with crossing smaller lines which resembles scars with stiches. The code "visual fake smile" alludes to a category that is characterised by a depiction of a mouth that is covered with a smile. In this example the person is wearing a mask with a smile that covers the face, ${ }^{10}$ more common was that the mouth was hidden behind a stylised "smiley" mouth (see figure 2). The representation of a fake smile in Sweetwii044's meme is a contradiction between the iconic elements (smile = feeling fine vs scars with stiches = self-injury, which is connected to mental distress). The nodes "contradiction text and image" and "contradiction between text and text" captures other ambiguous features of Sweetwii044's meme. "I'M FINE" that stands out in glowing red in the upper part of the meme is contradicted by the images' scars (but affirmed by the faked smile) and the statement is also contradicted by the content of other textual elements in the meme: death, misunderstood and fear to mention a few.

This analysis with its quantitative approach creates an overview of a field. Further analysis should scrutinise the memes mentioned, the context that they are part of and also the intentions behind the creation and publication of them. Such a qualitative approach would deepen the understanding of the memes and the discourses they appear in.

\footnotetext{
${ }^{10}$ In the original this is quite clear as the mask is represented in white that contrasts to the pink arms.
} 


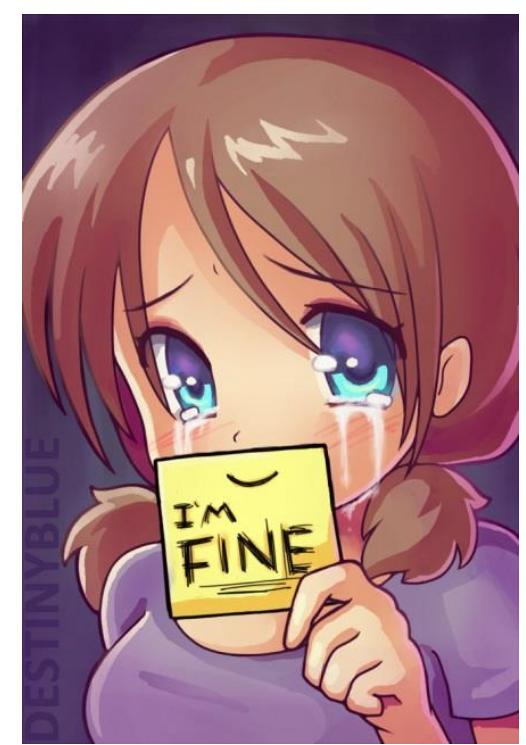

Figure 2. DestinyBlue I'm Fine (C) DestinyBlue 2011. Published with permission from the copyright holder

\section{Results}

When the material had been analysed three mayor categories related to intermedia relation had emerged: Contradictions between text and image; contradiction between textual elements; and no contradiction between text and image. Memes in the category with contradictions between text and image dominated in the material (it appeared in nine out of ten memes), these were further divided into subcategories based on visual iconic representations. This process resulted in the following list beginning with the most common: Contradictions achieved through visual representations of body posture or action, fake smile, self-injury, or scar/tattoo. Apart from the already mentioned categories a quite large group of memes named "bipolar", in which individuals were separated into one sad and one happy half. These memes was based on a contradiction between visual iconic representations of the person with a happy side that affirmed the textual content.

Individuals depicted in the memes are, with few exceptions, alone. In cases where two persons appeared, they often, judging from the similarity in clothes, hairstyle and other attributes, seemed to represent different aspects of the same individual. Representations of females were four times more common than those of males $(n=168,79 \%$ compared to $n=45$, $21 \%) .{ }^{11}$ In memes in which the iconic and textual content corresponded, a slight overrepresentation of males was noted. Males showing significant signs of mental distress, as in the female versions, did appear in the material. But a notable number of memes represented a discourse of brave men who can take a punch (although this is illustrated with a certain amount of irony). One example of this theme is a depiction of the comic superhero Spiderman, with a sword and sticks stuck into his body, saying, "I'm fine." No females were represented in this type of meme. A tendency for aggressive and violent themes was noticed in I'm-fine memes with representations of male individuals. Examples of these are mutilated

\footnotetext{
${ }^{11}$ I'm-fine memes where gender were impossible to detect or those with animals, symbols etc are not addressed in this article.
} 
bodies or figures with sharp objects stuck into them, such as one meme which has an axe chopped into the figure's head.

The notion that the text saying "I'm fine" is articulated as mental distress in the material is grounded on the text's indexical relation (in which closeness indicate likeness) with a specific sign. Together these signs create something like a mental distress iconography, where affects and feelings are manifested through significant elements. Reoccurring signs related to bodies are tears, blood, wounds and scars, hidden faces and eyes that are hidden, turned away or looking far into the distance. Frequent gestures and positions are hands covering a face or eyes, and arms that are hugging, held around or holding together the individuals. ${ }^{12}$ Among the symbolic signs are broken hearts, craniums and skeletons, wastelands and raindrops. Signs of self-destruction, such as razorblades held to an arm, a gun against the temple, and snares, occur frequently in the material. The eyes and mouth are often accentuated elements of I'm-fine memes. As in figure 2, the depicted person is often looking out of the image and in this way establishing an imagined connection with the beholder. Eyes are also the generators of tears, the most frequent sign indicating mental distress in the material.

Often, some parts of the image are covered by another image or by a text strip. In the example with the fake smile (figure 2), the smile was in the same visual mode (style) as the rest of the image. Another version of this is where the smile is placed in a layer that is visually covering some of the image below, like in a collage. Another category that is seen very frequently is memes is when a text strip is used to comment on and/or cover parts of the image. It seems as though it is important to show the signs of feeling to some extent, the feelings should be detectable but not shown too much. I will return to this aspect. In one image the mouth is covered with a strip of fabric with "I'm FINE" written on it. The gag is indicates something that it is not possible or aloud to say out loud.

So far the analyse show how "I'm fine" in the meme analysed here is related to signs that contradicts its textual meaning. This contradiction is made through signs, elements and moments that, allude to mental distress and femininity. The analyse suggest that male bodies are apprehended as unsuitable to represent mental distress, at least in the ambiguous way that is represented in the I'm-fine meme. In short: The phrase "I'm fine" in the material should predominantly be understood as "I'm not fine" and that the statement is connected to females, through coded bodies, or femininity, through coded bodily gestures, positions or poses.

The I'm-fine meme is part of a discourse that articulates mental distress in a consistent way. As in other discourses, single statements (including mediums other than image and text) work together in articulating mental distress and how it should be represented. Thus, it is not necessary for all aspects of mental distress to be present in every single case. Together, these memes and other representations create a consistent whole in which signs for femininity have a dominating position. This relation between mental illness and female bodies or femininity is in line with the research mentioned above.

In the material elements, like signifiers for bodies (iconic) or symbolic content, frequently were related to a signifying chain of equivalence (Laclau \& Mouffe 2001:128-129) that connected female with weakness and mental distress. Examples of these signs are eyes turned

\footnotetext{
${ }^{12}$ The identification of the gestures and bodily positions that relate to mental distress are based on previous studies see Sternudd \& Johansson 2015 respectively Johansson \& Sternudd 2015.
} 
away and broken hearts. In relation to the bodies represented in the memes, two central themes are crystallised, which gives a more complex articulation than described above: the gendered bodies are related to the nodes communication and feelings. Notable among the communicative aspects is that the persons in the memes are usually represented in close-ups, depictions that are similar to what is experienced when having a personal conversation (Kress \& Van Leeuwen 2006:124), and this is an interpretation that is strengthened by the look that is aimed at the beholder and the textual message involving "I". Portraits in which the depicted person is looking out of the image are generally understood as depicting subjects who are communicating with the viewer. However, this possible communication is often here hindered by visual insertions - eyes are shut or blocked with the positive statement "I'm fine." In a similar way, any potential utterances of words are blocked. But to complete the meme, the visual representations of feeling are at hand, for instance in the form of tears; that are distinct enough, so they cannot be ignored, but not too insistent and emotional. "I'm fine" could be an answer to the question: "How are you?" The answer could be understood as representing one of Grice's maxims that in relation to the conversational category Quantity states: "Do not make your contribution more informative than is required" (Grice 1975:47). But still the individual in the memes seem to want her feelings to be noted.

To understand this ambiguous approach to communicating mental illness, hegemonic articulations need to be taken into consideration. First of all, feelings are "things" that originate and are positioned inside bodies or minds. The common presence of eyes in I'mfine memes could be understood as related to proverbs like "The eyes are the mirror of the soul." Following this logic, a silenced mouth (covered by visual components, or created through gestures or gags) can be understood as a visual rhetorical means that is alluding to understandings of talk as an important way to achieve mental well-being. A silenced person lacks the opportunity to be released from their negative feelings as these are made sense of in mediations that are done through language. For example, in one meme I considered, which has several versions, the concept of feelings as something inherent in human beings is illustrated. Inside a silhouette of a head, the words "HELP ME" are repeated over and over again. From the mouth only two words are let out, the by now very familiar "I'm Fine ...." In a concise way, the meme shows not only how feelings reside inside a person but also the discrepancy between how much can dwell inside a person's mind and how little is allowed to get out. $^{13}$

But why don't the individuals in the I'm-fine meme talk? In the above-mentioned examples, images of closed eyes and silenced mouths are hindering signs that prevent conversation and communication about the experienced feelings. The message "I'm not fine!" is only implied, but not so much that it becomes intrusive. Even if these protective measures are a correct relation in the chain of equivalence, the questions that still remain are what is on the other end of the chain and what are these females protected from? In the article "Self-injuring girls' - cutting and the importance of gender", ${ }^{14}$ Johansson describes how girls who self-injure are expected to perform their mental distress in a respectable way. Individuals who

\footnotetext{
${ }^{13}$ This concept of inherent feelings has been questioned by Lutz and Abu-Lughod (1990). According to them, feelings should be understood as a relational interpersonal activity that emanates from contact between individuals.

${ }^{14}$ Title translated by the author.
} 
are positioned in an intersection where health, age and gender meet at the point: mental distress-young-female are facing the challenge of succeeding in being modest in their expressions while still showing a certain degree of illness (Johansson 2010b). A respectable self-injurer must draw a strict line between herself and so-called fashion cutters, who only seek attention, at the same time as presenting recognisable signs of illness. ${ }^{15}$

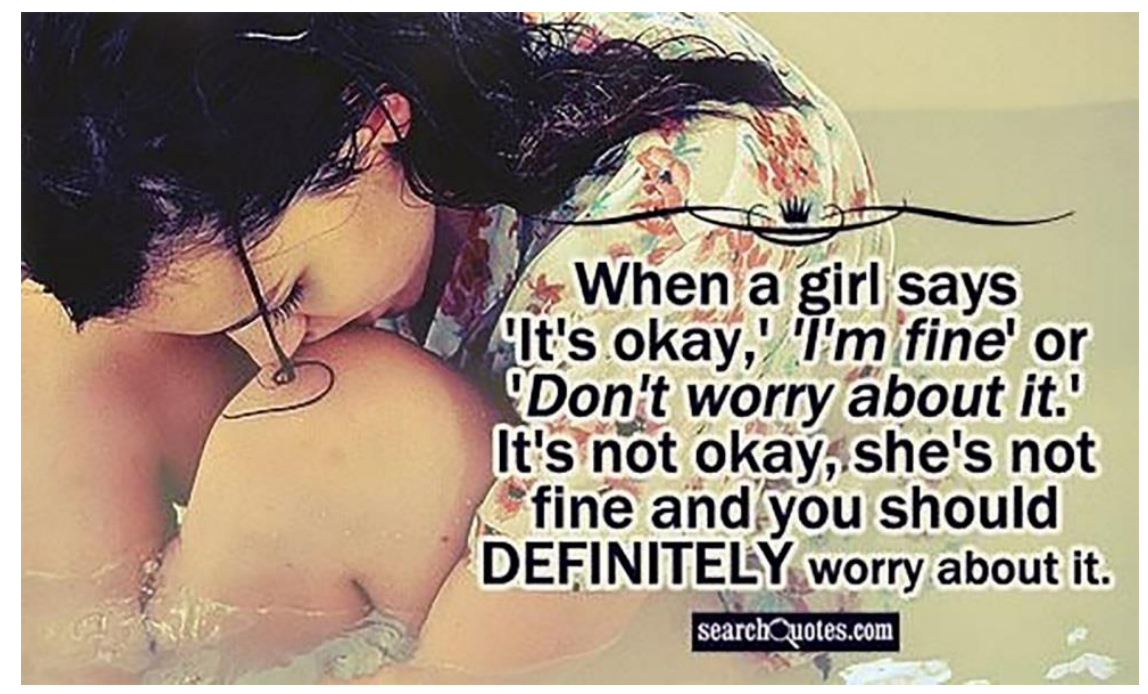

Figure 3. Remix of Olivia Megalis: Woman in bathtub (C) Getty Images 2016. Published with permission from the copyright holder

Arguably, it is possible to inscribe the I'm-fine meme in the discourse that Johansson is describing. This is most obviously the case for the category of I'm-fine memes in which the meaning of the phrase is explained. An example of this is figure 3, which shows a girl sitting in what is probably a bathtub with her clothes on, in a typical position that connotes mental distress (see Johansson \& Sternudd 2015; Sternudd \& Johansson 2015). On the photo is written: "When a girl says 'It's okay,' 'I'm fine' or 'Don't worry about it.' It's not okay, she's not fine and you should DEFINITELY worry about it." In this example, not only is an explanation on what girls actually mean given, but an adequate reaction is prescribed.

The answer to the question of what these females are protected from could, following the logic of the reasoning, be that the individuals represented in the memes, as well as those who can identify themselves with them, are protected from themselves. Because someone that expresses their mental distress in an uncontrolled way runs the risk of not receiving the attention and care they may be trying to obtain.

\section{Concluding remarks}

The results have shown that bodies coded as male seems to be inadequate to represent introvert suffering in the I'm-fine meme. It also showed that individuals coded as females were overrepresented in the I'm-fine meme, they were articulated as people who hide their real feelings in different ways. Discursively, this understanding is anchored in conceptions of girls and women as individuals who do not mean what they are saying, a kind of femininity signified by illogicality and unpredictable ways of communicating - people who say the

\footnotetext{
${ }^{15}$ On these borders see Johansson 2011.
} 
opposite of what they mean. This is important because it says something about notions of femininity and also because this articulation provides a subject's position that it is possible to identify with. The latter gives the discourse a disciplinary potential, which prescribes that certain expressions of feelings should be done in a recognisable way - with modesty and without excess. Even if the two media that constitute the meme seem to be contradicting each other, together they establish a consistent intermedial sign in a dominating articulation connecting femininity and mental weakness.

With this conclusion this study contributes to previous studies on the restrictions of possibilities expressions for young females' in certain contexts. By analytically highlighting this in a material that is not been done before, as least to my knowledge, the constructive character of representations of mental illness and possible of the condition itself is lifted forward. Hopefully this contributes to a reconstruction of how suffering is displayed and understood, a reformulation that must be grounded on alternative articulations of femininity and what it means to be female.

\section{References}

Bergström, Irja. 2001. Ester Henning: Kvinnoöde, konstnärsdröm, anstaltsliv. Stockholm: Carlsson.

Butler, Judith. 2006 [1990/1999]. Gender trouble: Feminism and the subversion of identity. New York: London: Routledge. [electronic resource].

Börzsei, Linda K.. 2013. "Makes a meme instead: A concise history of internet memes". New Media Studies Magazine 7. P. 1-28.<http://works.bepress.com/linda_borzsei/2/> [Available 12 October 2015].

Cullberg, Johan. 1999. "Carl Fredrik Hill personen och sjukdomen”. In Karin Sidén (ed.), Carl Fredrik Hill (catalogue). Stockholm: Nationalmuseum. P. 117-127.

Davison, Patrick. 2012. "The language of internet memes". In Michael Mandiberg (ed) The social media reader. New York and London: New York University Press. P. 120-124. $<$ https://archive.org/details/TheSocialMediaReader> [Available 20 January 2016].

Dawkins, Richard. 2006[1976]. The selfish gene. Oxford: Oxford University Press.

Dias, Karen. 2003. "The ana sanctuary: Women's pro-anorexia narratives in cyberspace". Journal of international women's studies 4(2). P. 31-44.

DeviantArt. 2016. "About DeviantArt: At DeviantArt, we bleed and breed art". <http://about.deviantart.com/> [Available 7 Mars 2016].

Edmondson, Amanda Jane. 2013. Listening with your eyes: Using pictures and words to explore self-harm. PhD thesis, University of Leeds.

Elleström, Lars. 2010. "The modalities of media: A model for understanding intermedial relations". In Lars Elleström (ed) Media transformation: The transfer of media characteristics among media. Houndsmill, Basingstoke, Hampshire: Palgrave Macmillan. P. 11-48.

Giles, David. 2006. "Constructing identities in cyberspace: The case of eating disorders". British Journal of Social Psychology 45. P. 463-477.

The Global Media Monitoring Project .2015. "Who makes the news?" <http://whomakesthenews.org/gmmp/gmmp-reports/gmmp-2015-reports> [Available 8 December 2016].

Google Images. <https://images.google.com> [Search 22, 25 September, 2 October 2015.].

Grice, Paul. 1975. "Logic and conversation". In Peter Cole \& Jerry L. Morgan. Syntax and semantics: Vol. 3: Speech Acts. New York: Academic Press. P. 41-58. 
Hacking, Ian. 1999. The social construction of what? Cambridge, Mass.: Harvard Univ. Press.

Internet Live Stats. 2016. Google search statistics. <www.internetlivestats.com/googlesearch-statistics> [Available 17 February 2016].

Hsieh, Hsiu-Fang, and Sarah E. Shannon. 2005. "Three approaches to qualitative content analysis". Qualitative Health Research 15. P.1277-1288.

Johannisson, Karin. 1994. Den mörka kontinenten: kvinnan, medicinen och fin-de-siècle. Stockholm: Norstedt.

Johansson Anna. 2010a. Självskada: En etnologisk studie av mening och identitet i berättelser om skärande. Diss. Umeå: Umeå universitet/h:ström - Text \& kultur.

Johansson Anna. 2010b. "Självskadetjejer" - skärande och betydelse av kön." In Anna-Karin Frih och Eva Söderberg (eds), En bok om flickor och flickforskning, Lund: Studentlitteratur. P. 87-93.

Johansson Anna. 2011. Constituting "real" cutters: A discourse theoretical analysis of selfharm and identity. In Annika Egan Sjölander and Jenny Gunnarsson Payne (eds.), Tracking discourses: Politics, identity and social change, Lund: Nordic Academic Press. P. 197-224.

Johansson, Anna \& Hans T. Sternudd. 2015. "Iconography of Suffering in Social Media: Images of Sitting Girls". In Ronald E. Anderson (ed.) World Suffering and Quality of Life. New York: Springer. P. 341-355.

Johansson, Anna \& Hans T. Sternudd. 2016. "Ridiculing Suffering on YouTube: Digital parodies of emo style". In Nate Hinerman and, Holly Lynn Baumgartner (eds.), Blunt Traumas: Negotiating Suffering and Death. Oxford: Inter-Disciplinary Press. P. 31-40.

Knobel, Michele \& Colin Lankshear. 2005. "Memes and affinities: Cultural replication and literacy education”. Paper presented to the annual NRC, Miami, November 30, 2005. CiteSeer ${ }^{X}<$ http://citeseerx.ist.psu.edu/viewdoc/summary?doi=10.1.1.89.5549> [Available 20 January 2016].

Kress, Gunther R. \& Theo Van Leeuwen. 2006. Reading images: The grammar of visual design. 2. ed. London: Routledge.

Laclau, Ernesto \& Chantal Mouffe. (1985) 2001. Hegemony and Socialist Strategy: Towards a Radical Democratic Politics. London and New York: Verso.

Lutz, Catherine A. \& Lila Abu-Lughod (red.). 1990. Language and the Politics of Emotion. Cambridge: Cambridge University Press.

Lutz, Catherine A. \& Collins, Jane L. (1993). Reading National Geographic. Chicago: University of Chicago Press.

MacGregor, John M. 1989. The discovery of the art of the insane. Princeton, New Jersey: Princeton University Press.

Marner, A. (1999): Burkkänslan, surrealism i Christer Strömholms fotografi, en undersökning med semiotisk metod. (Doctoral dissertation). Umeå: Institutionen för konstvetenskap, Institutionen för estetiska ämnen, Umeå universitet.

Milia, Diana. 2000. Self-mutilation and art therapy: Violent creation. London: Jessica Kingsley.

Myhre, Ben. 2012. "Difference between memes and going viral". Sundog. <https://www.sundoginteractive.com/blog/difference-between-memes-and-going-viral> [Available 20 January 2016].

Nakamura, Lisa. 2008. Digitizing race: Visual cultures of the Internet. Minneapolis: University of Minnesota Press.

Nilsson, Sten Åke. 1977. Hillefanten: Konstvetenskapliga studier. In C. F. Hills värld. Lund: Cavefors. 
Nagera, Humberto. 1979. Vincent van Gogh: A psychological study. London: George Allan \& Unwin Ltd.

Pollock, Griselda. 2007. What does a woman want? Art investigating death in Charlotte Salomon's leben? Oder theater? Art history. 30(3). P 383-405.

Pollock, Griselda. 2012. Selv-fortælling: Frida Kahlos politiske forestillinger. In Christian Gether, Stine Høholt, Marie Laurberg \& Naja Rasmussen (eds.), Frida Kahlo: Et liv $i$ kunsten, Ishøj: Arken Museum for moderne kunst. P. 26-40.

Rose, Gillian. 2012. Visual methodologies: An introduction to researching with visual materials. 3rd ed. London: Sage.

Sandström, Lotta \& Eva E. Johansson. 2004. Depression i läkemedelsannonser. In Birgitta Hovelius \& Johansson, Eva E. (eds.) Kropp och genus i medicinen. Lund: Studentlitteratur. P. 305-314.

Shifman, Limor. 2011. An anatomy of a YouTube meme. New media \& society 14(2). P. 187-203. DOI:10.1177/1461444811412160.

Showalter, Elaine. 1987. The female malady: Women, madness and English culture 18301980. London: Virago.

Sobek, Markus. 2003a. A Survey of Google's PageRank. eFactory. < http://pr.efactory.de/> [Available 22 January 2016].

Sobek, Markus. 2003b. The PageRank algorithm. <http://pr.efactory.de/e-pagerankalgorithm.shtml> [Available 22 January 2016].

Sternudd, Hans T. 2012. Photographs of self-injury: Production and reception in a group of self-injurers. Journal of Youth Studies 15 (4). P. 421-436.

Sternudd, Hans T. 2014. "I like to See Blood": Visuality and self-cutting. Visual Studies 29 (1). P. 14-29.

Sternudd, Hans \& Anna Johansson. 2015. The girl in the corner: Aesthetics of suffering in a digitalized space. In Lolita Guimarães Guerra \& Jose A. Nicdao (ed.), Narratives of suffering: Meaning and experience in a transcultural approach. Oxford, InterDisciplinary Press. P. 105-115.

Starwa. 2011. 'I'm fine'. DeviantArt < http://starwa.deviantart.com/art/I-m-fine-227152097> [Available 13 December 2016].

Sweetwii044. 2012. I'm Fine. DeviantArt < http://sweetwii044.deviantart.com/art/I-m-Fine341667731> [Available 13 December 2016].

Tatman, Lucy. 2012. The other thing about suffering. In Jeff Malpas and Norelle Lickiss (eds.), Perspectives on human suffering, New York: Springer. P. 43-48.

TinEye Reverse Image Search.[https://www.tineye.com].

Ussher, Jane. M. 2011. The madness of women: Myth and experience. London: Routledge.

Ward, Katie J. 2007. 'I love you to the bones': Constructing the anorexic body in 'pro-ana' message boards. Sociological research online 12(2). <http://www.socresonline .org.uk.ludwig.lub.lu.se/12/2/ward.html> [Available 31 Mars 2009].

Wikipedia. 2016. DeviantArt. 〈https://en.wikipedia.org/wiki/DeviantArt> [Available 30 Mars 2016].

Winther Jørgensen, Marianne \& Louise Phillips. 2002. Discourse analysis as theory and method. London: Sage.

White, Michele (2006). The body and the screen: Theories of Internet spectatorship. Cambridge, Massachusetts: MIT Press.

Zetterman, Eva. 2003. Frida Kahlos bildspråk: Ansikte, Kropp \& Landskap: Representation av nationell identitet. Diss. Göteborg: Acta Universitatis Gothoburgensis. 